\title{
PREFACE
}

\section{Mechanisms of metasomatic reactions}

\author{
Daniel E. Harlov • Horst R. Marschall
}

Published online: 12 February 2009

(C) Springer-Verlag 2009

Fluid-aided mass transfer and subsequent mineral re-equilibration are the two defining features of metasomatism and must be present in order for metamorphism to occur. Taking into account geological time scales, the amount of fluid required need not be great (considerably less than $0.01 \%$ of the total volume) nor even in continuous flow but the fluid must be chemically reactive with respect to the minerals it encounters as well as promote efficient mass transfer. Evidence for the passage of fluids through rock can take the form of altered mineral trace element chemistry, partial to total re-equilibration of all mineral phases, as well as reaction textures along mineral grain boundaries. In addition, both reactive and non-reactive fluids can and often do leave behind traces of their passage in the form of fluid inclusions.

Coupled with igneous and tectonic processes, metasomatism has played a major role in the formation of the Earth's continental and oceanic crust as well as in their evolution and subsequent stabilization. Metasomatic processes can include ore mineralization (Wilkinson and Kesler 2007); metasomatically induced alteration of oceanic lithosphere (Hopson et al. 2008); mass transport in and alteration of subducted oceanic crust and overlying mantle wedge (Zack and John 2007), which has subsequent implications regarding mass transport, fluid flow, and volatile storage in the lithospheric mantle overall (Mukasa

\footnotetext{
D. E. Harlov $(\bowtie)$

Deutsches GeoForschungsZentrum,

Telegrafenberg,

Potsdam 14473, Germany

e-mail: dharlov@gfz-postsdam.de

H. R. Marschall

Department of Earth Sciences, University of Bristol,

Wills Memorial Building, Queen's Road,

Bristol BS81RJ, UK

e-mail: Horst.Marschall@bristol.ac.uk
}

et al. 2007), as well as both regional (Ordonez et al. 2008) and localized crustal metamorphism (Harlov et al. 2006). Metasomatic alteration of accessory minerals such as zircon (Geisler et al. 2007) or monazite (Dumond et al. 2008) can allow for the dating of metasomatic events as well as give additional information regarding the chemistry of the fluids responsible.

Papers submitted to this volume cover a wide diversity of topics with regard to metasomatism. These range from low- to high-grade processes and from upper-crustal shear zones and veins to high and ultra-high pressure metamorphic rocks as well as rocks from the lithospheric mantle. In the first paper, Glodny and Grauert investigate low temperature $\left(100-200^{\circ} \mathrm{C}\right)$ elemental $(\mathrm{K}, \mathrm{Cl}, \mathrm{Na}, \mathrm{Ca})$ and $\mathrm{Rb}-\mathrm{Sr}$ isotopic changes associated with the formation of zoned alteration halos along post orogenic hydrothermal veins in a metaquartzdioritic Variscan gneiss from the Artenberg quarry near Steinach, Kinzigtal, Schwarzwald, SW Germany. Sengupta et al. next describe a series of granulite-facies $\left(750^{\circ} \mathrm{C} ; 900 \mathrm{MPa}\right)$ skarns associated with marbles and calc-silicate rocks in migmatitic metapelites located near Sittampundi, south India. Here, aqueous fluids, derived from prograde metamorphism of the metapelites, are hypothesized to be the likely source for the metasomatic fluids responsible for the formation of the skarns. In a related paper, Hansen and Harlov describe granulite-facies orthopyroxene-bearing leucosomes with subordinate biotite in finer grained hornblende-biotite-pyroxene-bearing migmatites from Cone Peak, California, USA $\left(700-750^{\circ} \mathrm{C}\right.$; $750 \mathrm{MPa}$ ) and the Satnur-Sangam road, Southern Karnataka, India $\left(700-800^{\circ} \mathrm{C} ; 500-600 \mathrm{MPa}\right)$. Compositional differences between the paleosome and neosomes at Cone Peak are best explained by metasomatic interaction with concentrated brines while elevated $\mathrm{Cl}$ concentrations in fluorapatites in the leucosome suggest interaction with a 
Cl-bearing fluid. In contrast, while brines may have been responsible for an exchange of elements between the host rock and zones of melt generation along the SatnurSangam road, fluid flow was probably less vigorous than at Cone Peak. Continuing with investigations of the lower crust, Degi et al. examine the effects of xenolith-host basalt interaction in lower crustal mafic granulite xenoliths from the Central Pannonian Basin, Hungary. Lamellar titanomagnetite-ilmenite intergrowths are chemically overprinted to a significant extent. This chemical alteration is diffusioncontrolled and allows for the duration of xenolith-host basalt interaction to be estimated. Going from the lower crust to the lithospheric mantle, Scribano et al. describe three types of ultramafic xenoliths from the Hyblean area (Sicily), which show primary evidence for mantle metasomatism. The nature and abundance of some fluid-mobile elements suggest that some hydrous fluids may be derived from hydrothermally altered oceanic crust. Silicate melts probably have a deep-seated origin, which suggests a key role for mantle metasomatism in the origin of some alkaline Hyblean magmas. On a more localized scale, Marocchi et al. investigate the metasomatic contact zone between peridotite lenses and host gneisses located on the northern side of the Hochwart peak, Ulten Zone, Alto AdigeSüdtirol, Italy. The formation of the reaction zone was triggered by considerable fluid/melt circulation, causing crystallization of mainly phlogopite, anthophyllite, and talc coupled with the release of a trondhjemitic residual melt. It involved extensive addition of $\mathrm{H}_{2} \mathrm{O}, \mathrm{K}_{2} \mathrm{O}$, and LILE from the fluid, whereas $\mathrm{MgO}, \mathrm{CaO}$, and $\mathrm{Al}_{2} \mathrm{O}_{3}$ were removed from the peridotite. The exposed contact between the peridotites and host gneisses is taken as a natural laboratory to investigate the physico-chemical and mineralogical processes operating at the slab-mantle interface during active subduction and exhumation. Continuing with ultramafic rocks, Toksoy-Köksal et al. describe a metasomatised ultramafic-mafic cumulate body from Kurancali, central Anatolia, Turkey. These cumulates crystallized from a magma derived from mantle source(s) metasomatised by an $\mathrm{H}_{2} \mathrm{O}$-, alkali-, carbonate-rich aluminosilicate melt and fluids, which likely were derived from a subducted slab. High-pressure metamorphosed igneous rocks $\left(500^{\circ} \mathrm{C}\right.$; 1,300-2,000 MPa) from the island of Syros, Greece, along with their metasomatised rinds, are analysed for $\mathrm{Li}, \mathrm{B}, \mathrm{Be}$, $\mathrm{Cl}$, and $\mathrm{H}_{2} \mathrm{O}$ using photo-spectrometric and neutron activation techniques by Marschall et al. Their study suggests that $\mathrm{B}$ and $\mathrm{Cl}$ abundances in these rocks can be used to trace prograde dehydration, while Li concentrations seem to be more sensitive to retrograde metasomatic processes in such lithologies. In metapelites from the Saualpe complex (Eastern Alps), Prenzel et al. describe
10-20 $\mu \mathrm{m}$-wide garnet reaction rims along biotite-plagioclase and biotite-perthite interfaces, which grew during a Cretaceous eclogite-facies overprint. Garnet reaction rim growth involved transfer of $\mathrm{Fe}$ and $\mathrm{Mg}$ components from the garnet-biotite interface to the garnet-feldspar interface coupled with the transfer of the $\mathrm{Ca}$ component in the opposite direction resulting in complex asymmetrical chemical zoning in the garnet rims. Utilizing numerical modeling, it is demonstrated that the abundance of grain boundaries in the garnet reaction rim is the first order control with respect to its internal chemical zoning. Continuing with studies of eclogites, Cheng et al. investigate atoll-garnets in an eclogite from the Dabie orogen, east-central China, which are suggested to have resulted from a fluid-enhanced overgrowth at the onset of exhumation. Comprehensive textural, chemical, and Lu-Hf geochronological analysis of these garnets place better constraints on the timing of retrograde fluid activity and allow for insights into isotopic equilibrium and/or disequilibrium during exhumation. Lastly, in the one experimental petrology paper submitted to this volume, Huang et al. measure the reaction rate of dolomite + aragonite $=\mathrm{Mg}$-calcite at $800^{\circ} \mathrm{C}, 850^{\circ} \mathrm{C}$, and $900^{\circ} \mathrm{C}$ and $1,600 \mathrm{MPa}$ under $\mathrm{H}_{2} \mathrm{O}$ absent conditions. The dolomite-aragonite aggregate transforms very rapidly into a dolomite-calcite polycrystalline aggregate while the $\mathrm{Mg}$-calcite forms at a relatively slower rate becoming progressively richer in $\mathrm{Mg}$ as a function of run time. Reaction progress was modeled semi-empirically using the first-order rate law and indicates that, in the absence of a metamorphic fluid, $\mathrm{Mg}$-calcite may not reach $\mathrm{Mg}$-saturation until temperatures corresponding to mid-grade metamorphism are reached whereas $\mathrm{Ca}-\mathrm{Mg}$ inter-diffusion appears to cease at temperatures below $480^{\circ} \mathrm{C}$.

Acknowledgements The guest editors wish to thank Editorin-Chief Rainer Abart for his support of the special issue, and the technical editor for Mineralogy and Petrology Judy Pieren for her technical support in all logistical aspects of this project. We would also like to express our thanks to the following reviewers: Wolfgang Bach, Bremen, Germany; Mark Colberg, Cedar City, Utah, USA; Marco Scambelluri, Genova, Italy; Magali Bonifacie, Pasadena, California, USA; Alessandra Montanini, Parma, Italy; Massimo Coltorti, Sydney, Australia; Ralf Milke, Berlin, Germany; Thomas Müller, Bochum, Germany; Gerlinde Habler, Vienna, Austria; Georg Hoinkes, Graz, Austria; M Santosh, Kochi, Japan; Jay Ague, New Haven, Connecticut, USA; Simone Tumiati, Como, Italy; Gray Bebout, Bethlehem, Pennsylvania, USA; Penelope Lancaster, Bristol, United Kingdom; Michael Williams, Amherst, Massachusetts, USA; John Schumacher, Bristol, United Kingdom; Tassos Grammatikopoulos, Patras, Greece; Shoji Arai, Kanazawa, Japan; Aral Okay, Istanbul, Turkey; Yong-Fei Zheng, Hefei, Peoples Republic of China; Thomas Lapen, Houston, Texas, USA; Pavla Stipska, Prague, Czech Republic; Gary Solar, Buffalo, New York, USA; Niels Jöns, Bremen, Germany. 


\section{References}

Dumond G, McLean N, Williams ML, Jercinovic MJ, Bowring SA (2008) High-resolution dating of granite petrogenesis and deformation in a lower crustal shear zone:Athabasca granulite terrane, western Canadian Shield. Chem Geol 254:175-196

Geisler T, Schaltegger U, Tomaschek F (2007) Re-equilibration of zircon in aqueousfluids and melts. Elements 3:43-50

Harlov DE, Johansson L, Van den Kerkhof A, Förster H-J (2006) The role of advective fluid flow and diffusion during localized, solid-state dehydration: Söndrum Stenhuggeriet, Halmstad, SW Sweden. J Petrol 47:3-33

Hopson CA, Mattinson J, Pessagno EA, Luyendyk BP (2008) Californian Coast Range Ophiolite; composite Middle and Late
Jurassic oceanic lithosphere. Special Paper-Geological Society of America vol. 438, pp 102

Mukasa SB, Blatter DL, Andronikov AV (2007) Mantle peridotite xenoliths in andesite lava at El Penon, central Mexican volcanic belt; isotopic and trace element evidence for melting and metasomatism in the mantle wedge beneath an active arc. Earth Planet Sci Lett 260:37-55

Ordonez C, Polat A, Fryer BJ, Gagnon JE, Raith JG, Appel PWU (2008) Evidence for HFSE and REE mobility during calc-silicate metasomatism, Mesoarchean (approximately $3075 \mathrm{Ma}$ ) Ivisaartoq greenstone belt, southern West Greenland. Precambrian Res 161:317-340

Wilkinson BH, Kesler SE (2007) Tectonism and exhumation in convergent margin orogens; insights from ore deposits. J Geol 115:611-627

Zack T, John T (2007) An evaluation of reactive fluid flow and trace element mobility in subducting slabs. Chem Geol 239:199-216 